\title{
Lägst ned på skalan? Hälso- och sjukvårdens bemötande av äldre kvinnor som migrerat till Sverige
}

\author{
HELENE BRODIN \& TITTI MATTSSON
}

\begin{abstract}
Det professionella bemötandet inom vård och omsorg kan påverkas av omedvetna värderingar som gör att personer upplever sig kränkta eller särbehandlade. Den här artikeln utforskar hur hälso- och sjukvården bemöter äldre kvinnor som migrerat till Sverige. Vi diskuterar spänningen mellan lika och likvärdigt bemötande och vilken relevans detta har för professionsutbildningar inom vård och omsorg.
\end{abstract}

\section{Inledning}

Socialtjänsten, äldreomsorgen och hälsooch sjukvården är alla verksamheter som

Helene Brodin är lektor vid Institutionen för socialt arbete, Stockholms universitet och Titti Mattsson är professor i offentlig rätt vid Juridiska fakulteten,Lunds universitet. Intervjustudien som artikeln baseras på finansierades av European Union Agency for Fundamental Rights (FRA). För Brodins del har själva arbetet med artikeln bekostats av programstödet Individanpassad omsorg och generell välfärd, finansierat av Forte. För Mattssons vidkommande ingår artikeln i ett projekt inom forskningsmiljön Äldrerätt, vilken miljö är finansierad av Ragnar Söderbergs stiftelse och Marianne och Marcus Wallenbergs stiftelse, www.jur.lu.se/elderlaw. styrs av lagar som syftar till ett likvärdigt bemötande av människor. Dessa verksamhetsområden arbetar också i huvudsak med människor som på olika sätt befinner sig i utsatta situationer. Mot den bakgrunden är det problematiskt när människor upplever sig bli diskriminerade i mötet med företrädare för dessa verksamheter (DO, 2014; FRA, 2013; Socialstyrelsen, 2011). Enligt diskrimineringslagen (2008:567) innebär diskriminering att någon missgynnas genom att bli sämre behandlad än personer i jämförbara situationer (4 §). Såväl internationell som svensk forskning visar att upplevelser av diskriminering, oavsett om de är juridiskt 
fastställda eller inte, påverkar individens hälsa negativt och leder till minskad tillit till samhälleliga institutioner och till andra människor (DO, 2014; Institute of Medicine (IOM), 2002; Wamala, Merlo, Boström \& Hogstedt, 2007). Upplevelsen av att bli diskriminerad i mötet med socialtjänsten, äldreomsorgen eller hälso- och sjukvården kan därför betraktas som särskilt kritisk därför att den försämrar förutsättningarna för människor som redan befinner sig i besvärliga livssituationer.

Diskrimineringsombudsmannen, DO, har analyserat över 800 anmälningar om diskriminering som inkom till myndigheten under de första sex månaderna av 2012 (DO, 2014). Analysen omfattar samtliga sju diskrimineringsgrunder ${ }^{1}$ inom områdena arbetsliv, kontakt med myndigheter som exempelvis socialtjänsten, samt hälso- och sjukvården, utbildningsväsendet och handel med varor och tjänster. Genomgången av anmälningarna visar att det finns ett mönster i upplevelsen av att vara utsatt för diskriminering, oavsett diskrimineringsgrund eller om det är en arbetsgivare, socialtjänsten eller hälsooch sjukvården som uppfattas som diskriminerande. För det första är diskriminering en komplex erfarenhet. Ofta finns en diskrepans mellan vad lagen definierar som diskriminering och vad den enskilde uppfattar vara diskriminerande. Vidare beskrivs vanligtvis diskriminering som en händelsekedja eller beteendemönster

1 Kön, könsidentitet eller könsuttryck, etnisk tillhörighet, religion eller annan trosuppfattning, funktionsnedsättning, sexuell läggning eller ålder. av systematiskt missgynnande. Slutligen uppfattas diskriminering generellt som orsakad av så kallad negativ stereotypifiering. Det innebär att diskriminering ofta handlar om att den enskilde upplever sig bli tillskriven ofördelaktiga egenskaper och bristande kapaciteter genom att bli associerad med fördomar om en viss grupp i samhället.

Överenstämmelsen i upplevelserna indikerar att det finns generella mekanismer bakom upplevelsen av bli diskriminerad, oavsett diskrimineringsgrund och samhällsområde. Det är därför relevant att undersöka processerna som resulterar $i$ att människor upplever sig bli missgynnade. Vidare tyder likheten i människors erfarenheter på att olika samhällsområden, som exempelvis socialtjänst och hälso- och sjukvård, kan ta lärdom av varandra för att motverka upplevelser av kränkningar och negativ särbehandling.

Den här artikeln fokuserar på hur hälso- och sjukvården bemöter äldre kvinnor som har migrerat till Sverige. Syftet är att mot bakgrund av hälso- och sjukvårdslagens (1982:763) intentioner om likvärdig vård utforska om det finns särskiljande praktiker i det professionella bemötandet av äldre kvinnliga migranter som resulterar i att de upplever sig bli kränkta eller missgynnade. Vi vill poängtera att vi inte undersöker om diskriminering förekommer ur ett juridiskt perspektiv. ${ }^{2} \mathrm{Vi}$ gör ingen jämförelse mellan de äldre kvinnliga migranternas erfarenheter och bemötan-

2 Enligt $13 \S$ diskrimineringslagen är diskriminering förbjuden i fråga om hälso- och sjukvården. 
det av andra grupper i hälso- och sjukvården, vilket är nödvändigt för att kunna fastställa diskriminering. Vårt mål är istället att lyfta fram processerna som gör att äldre kvinnliga migranter upplever sig kränkta eller missgynnade i mötet med sjukvården. Artikeln är disponerad enligt följande: först gör vi en kort sammanfattning om bemötandet av äldre personer generellt inom hälso- och sjukvården. Därefter introducerar vi våra teoretiska utgångspunkter och de metoder och det material som artikeln bygger på. Efter detta redogör vi för våra resultat och analys. Artikeln avslutas med en diskussion om resultatens relevans för professioner inom vård, omsorg och socialtjänst.

\section{Bemötandet av äldre personer $i$ hälso- och sjukvården}

Hälso- och sjukvårdslagen, HSL, som anger ramarna för patienternas vård och rättsliga ställning, ställer höga krav på likvärdig vård (prop. 2013/14:106). Likvärdighet uttrycks genom att ange krav på en "god vård" för alla. Kraven innebär att vården ska särskilt (1) vara av god kvalitet med en god hygienisk standard och tillgodose patientens behov av trygghet, (2) vara lätt tillgänglig, (3) bygga på respekt för patientens självbestämmande och integritet, (4) främja goda kontakter mellan patienten och hälso- och sjukvårdspersonalen, samt (5) tillgodose patientens behov av kontinuitet och säkerhet ( $2 \mathrm{a} \S \mathrm{HSL})$. Patienten ska vidare få möjlighet att påverka sin vård och ges individuellt anpassad information om sitt hälsotillstånd och om de metoder för undersökning, vård och behandling som finns.
Att hälso- och sjukvården inte lever upp till lagstiftningens intention om likvärdighet har uppmärksammats under senare år (DO, 2012; FRA, 2013; Socialstyrelsen, 2011). Äldre personer beskrivs i detta sammanhang generellt som en grupp som missgynnas av strukturella och organisatoriska förhållanden. Prestationsbaserad ersättning, som flera landsting införde parallellt med att vårdvalet blev obligatoriskt i primärvården 2010 (prop. 2008/09:29), premierar många och korta behandlingar på vårdcentralerna. Strukturellt sett missgynnar detta äldre personer som har komplexa vårdbehov och därför behöver längre tid för ett läkarbesök (Socialstyrelsen, 2011). Automatiserad telefonbokning som de flesta vårdgivare använder sig av idag kan bli en organisatorisk barriär. Äldre personer med hörselnedsättning och/eller kognitiv funktionsnedsättning kan få problem att kontakta sjukvården eftersom de kan ha svårt för att höra eller förstå vad som sägs (Hagman \& Östberg, 2010).

Men det finns även sociala och ekonomiska faktorer som påverkar bemötandet och behandlingen av särskilda grupper av äldre personer. Utbildning är en sådan faktor. Högutbildade äldre personer får relativt sett fler remisser till specialistmottagningar än lågutbildade (Socialstyrelsen, 2009). Högutbildade får också bättre och mer lämpliga läkemedelsbehandlingar vid hjärtinfarkt, hjärtsvikt och stroke än lågutbildade äldre personer (Socialstyrelsen, 2011). Att kön påverkar bemötande och behandling inom sjukvården är välbelagt $\mathrm{i}$ såväl svensk som internationell forskning (Cameron, Song, 
Mannheim \& Dunlop, 2010; Wamala \& Lynch, 2002; Schön, 2011). Könsskillnaderna förvinner inte med åldern. Äldre kvinnor får vänta längre på operationer vid bland annat gråstarr än äldre män och kvinnor är också äldre än män och har sämre kognitiv förmåga än män när de får en demensdiagnos (Socialstyrelsen, 2009). Jämfört med äldre män är det även vanligare att äldre kvinnor har en olämplig läkemedelsanvändning, framför allt när det gäller kombinationer av lugnande, ångestdämpande och antipsykotiska läkemedel (Socialstyrelsen, 2011). Beträffande såväl religion som etnicitet och/eller nationellt ursprung saknas systematisk kunskap om hur dessa förhållanden påverkar bemötande och behandling av äldre personer i sjukvården. Oavsett ålder är det emellertid vanligare att utlandsfödda personer upplever sig sämre bemötta och behandlade i sjukvården jämfört med svenskfödda personer (DO, 2012; Socialstyrelsen, 2011; Wamala et al, 2007).

\section{Teoretiska utgångspunkter}

Fineman (2004) hävdar i sin teori om utsatthet (vulnerability theory) att innebörden av att vara människa är utsatthet, och inte den autonoma, fria och oberoende ställning som traditionellt hävdas inom exempelvis rättsvetenskapen. Människans utsatthet påverkas inte bara av de personliga förutsättningarna under hennes liv, utan också av de institutionella förutsättningarna som kan variera i tid och rum (Fineman, 2008). Sådana sammanhang ignoreras av det rådande diskrimineringsparadigmet som förutsätter lik- värdiga positioner hos individer och inte beaktar skillnader i förutsättningar och förmågor. Fineman menar därför att likvärdighet inte kan uppnås enbart genom att förbjuda diskriminering på olika grunder och inom olika områden. Istället bör vi vända blicken mot de institutionella förutsättningarna, såsom exempelvis det organisatoriska och professionella hanterandet av patienter med olika ålder, kön och etnicitet inom hälso- och sjukvården, för att undersöka de reella förutsättningarna för likvärdighet.

Liksom Fineman betonar flertalet intersektionella forskare betydelsen av institutionella och organisatoriska förhållanden i skapandet av ojämlikhet (se de los Reyes \& Mulinari, 2005; Mattsson, 2010). Intersektionalitet är ett paraplybegrepp för olika vetenskapsteoretiska och metodologiska perspektiv och har vuxit fram ur forskning med en uttalad normkritisk ansats, som feministiska och antirasistiska studier (McCall, 2005). Vad som förenar perspektiven är en konstruktionistisk syn på makt. I ett intersektionellt perspektiv är makt ett fenomen som skapas och vidmakthålls genom socialt konstruerade skillnader. Kön, klass och etnicitet utgör här de grundläggande principerna för hur åtskillnad skapas och reproduceras (de los Reyes \& Mulinari, 2005). Skillnadstänkande baserat på kön, klass och etnicitet är dels kontextberoende. Hur åtskillnader utifrån kön, klass och etnicitet beskrivs och omsätts i handling är således betingat av rumsliga och historiska sammanhang. Dels sker skillnadstänkande simultant. Det betyder att kön, klass och etnicitet är positioner och identiteter som orga- 
niserar varandra i samtidiga processer. Bekönade positioner eller identiteter är därför på samma gång klassbaserade och etnifierade ordningar eller tillhörigheter. Genom att korsas med andra indirekta maktordningar och identiteter, som ålder, sexualitet och funktionsnedsättning, kan skillnadstänkande utifrån kön, klass och etnicitet förstärkas (Yuval-Davies, 2011). Med andra ord kan grundläggande ojämlikheter baserat på kön, klass och etnicitet accentueras om personen är äldre, har en funktionsnedsättning och/eller har andra preferenser än den heterosexuella normen.

Liksom Fineman (2004) pekar de los Reyes \& Mulinari (2005) på att likvärdighet innebär att beakta de sammanhang, förhållanden och förmågor som villkorar personers eller gruppers möjligheter här och nu. Likvärdighet är därför inte detsamma som likhet. Ojämlikhet går således inte att bemöta och motverka med handlingar som grundar sig på föreställningar om likhet. Ett sådant förhållningssätt får snarare motsatt effekt. På samma gång som det döljer befintliga ojämlikheter som villkorar olika personers nuvarande handlingsutrymme antar det att alla personer faktiskt har samma och lika möjligheter att agera. Då det inte åtgärdar grundproblemet om en ojämlik fördelning av resurser och kapaciteter blir således det faktiska utfallet av politiskt och professionellt handlande grundat på likhetstänkande att befästa status quo.

Vi anser att Finemans utsatthetsbegrepp i kombination med en intersektionell teoretisk ansats ger möjligheter att utforska komplexiteten i likvärdighet i hälso- och sjukvården. Dels öppnar detta upp för ett utforskande av hur skillnadstänkande skapas och upprätthålls inom ramen för sjukvården som institution (lagstiftning) och organisation (praktiskt dagligt handlande). Dels ger det möjlighet att jämföra konsekvenserna mellan handlingar grundade på likhetstänkande och handlingar grundande på likvärdighetstänkande. Hur uttrycks likhet jämfört med likvärdighet i sjukvården och hur formar dessa olika förhållningssätt mötet med den enskilde?

\section{Material och metod}

\section{Material}

Vår artikel bygger på en internationell intervjustudie som genomfördes 2011 i syfte att undersöka förekomsten av multipel diskriminering $\mathrm{i}$ sjukvården $\mathrm{i}$ fem EU-länder, däribland Sverige. I Sverige genomfördes totalt sett 59 intervjuer, samtliga i Stockholm och Malmö. Studien finansierades av European Union Agency for Fundamental Rights (FRA) som också har publicerat en rapport om huvudresultaten (FRA, 2013).

I den internationella studien intervjuades tre olika patientgrupper i respektive land: unga vuxna med intellektuell funktionsnedsättning, kvinnor med reproduktiva hälsoproblem samt äldre personer. Samtliga av dessa intervjupersoner hade en etnisk och/eller nationell minoritetsbakgrund. Vid sidan av de tre patientgrupperna intervjuades även representanter för olika professionella grupper i respektive land, dels personalgrupper inom 
primärvården och specialistsjukvården, dels tjänstemän och representanter för myndigheter och dels intresseföreningar.

Materialet till den här artikeln grundar sig på 37 av de totalt 59 intervjuerna som genomfördes i Sverige 2011. Av dessa intervjuer är 12 genomförda med äldre migranter, varav tre är män och nio är kvinnor. De resterande 25 intervjuerna är genomförda med professionella. I den här artikeln kommer vi att betona de äldre kvinnliga migranternas erfarenheter. Det beror på att jämfört med de äldre manliga migranterna så innehåller kvinnornas berättelser betydligt fler och upprepade exempel på upplevelser av att bli kränkt eller diskriminerad. ${ }^{3}$

Samtliga av de äldre migranterna var oavsett kön mellan 50 till 80 år vid tidpunkten för intervjun. Alla kommer från Sydvästasien eller Afrika. En del personer kom som barn eller unga till Sverige på 1960-talet medan andra har kommit som asylsökanden i medelåldern eller senare. Våra intervjupersoner speglar således både erfarenheter av att åldras som migrant och att migrera som äldre. Det är en viktig distinktion eftersom migrationen i sig innebär olika påfrestningar beroende på vilken ålder personen befinner sig i (Torres, 2006). Att migrera som äldre kan exempelvis upplevas som extra påfres-

3 Att utreda orsakerna till könsskillnaden i de äldre migranternas erfarenheter av att bli kränkta eller diskriminerade faller utanför syftet med denna artikel. Generellt är det dock vanligare att kvinnor upplever sig blir diskriminerade i sjukvården än män (se DO, 2012; Wamala et al, 2007). tande eftersom hög ålder kan göra det svårare att lära sig ett nytt språk.

\section{Metod}

Utgångspunkten för den internationella intervjustudien var hur sjukvården bemöter och behandlar migranter och etniska minoriteter som befinner sig i skärningspunkten mellan flera utsatta positioner (etnicitet, kön, ålder och/eller funktionsnedsättning). Studiens analytiska utgångspunkt kan därför liknas vid det McCall (2005) kallar för intrakategorisk komplexitet. Det innebär att utforska hur makt och ojämlikhet skapas och upprätthålls med utgångspunkt $i$ en bestämd grupp. "Black feminism" och dess fokus på svarta kvinnors livsvillkor i USA är kanske den mest kända representanten för denna intersektionella inriktning. Den feministiska funktionshinderforskningen är ett annat exempel (se Garland-Thomson, 1997). Oftast är avsikten med denna forskningsinriktning att visa hur dikotoma tankemodeller (som man-kvinna eller svartvit) innebär att vissa positioner och identiteter marginaliseras inom en bestämd grupp. Därför är att synliggöra undanträngda och underordnade positioner och identiteter vanligtvis det övergripande syftet med dessa studier. Vårt fokus på de äldre kvinnliga migranternas erfarenheter kan också sägas utgå från ambitionen att ge röst åt en marginaliserad grupp. Som påpekades inledningsvis saknas i stort sett studier som belyser hur etnicitet och/ eller nationalitet samspelar med ålder och kön i bemötandet i svensk sjukvård (jfr Fioretos, 2009). 
Samtliga intervjuer genomfördes med hjälp av semistrukturerade intervjuguider ordnade utifrån vissa gemensamma teman, som exempelvis hälsa, behov, barriärer i tillgången till sjukvård och erfarenheter av diskriminering. Vissa teman var emellertid specifika för de olika informantgrupperna. Exempelvis frågade vi personalen om de har speciella tillvägagångssätt i mötet med migranter medan vi frågade äldre migranter om de har stöd och hjälp i hemmet av andra personer. Fem av de 12 intervjuerna med de äldre migranterna genomfördes med hjälp av tolk (varav en med en man och fyra med kvinnor). Vid intervjuns början tillfrågades samtliga personer om de ville definiera sin etnicitet och religion. När vi i artikeln refererar till begrepp som exempelvis muslimsk kvinna är det således en identitet som personen ifråga valt själv.

Målsättningen att ge röst åt marginaliserade grupper innebär en dubbel läsning av forskningsmaterialet (Garland-Thomson, 1997). Å ena sidan måste materialet läsas som sanna empiriska skildringar, det vill säga forskaren måste låta berättelsen framträda utan egna tolkningar eller tillrättalägganden. $\AA$ andra sidan måste berättelsen relateras till kontexten, alltså de sammanhang av makt, skillnadsskapande och underordning i vilket berättelsen framträder. Det kan exempelvis ske genom att visa hur centrala teman i berättelsen knyter an till diskurser och praktiker baserade på socialt konstruerade skillnader.

Den dubbla läsningen är en central metodologisk ansats i den här artikeln. Den innebär att vi har gjort ett medvetet perspektivval och låtit de äldre kvinnliga migranternas berättelser styra vår tolkning av resultatet. De professionellas erfarenheter har följaktligen underordnats de äldre kvinnliga migranternas upplevelser. Vi har valt detta tillvägagångssätt eftersom denna artikel undersöker kvinnornas erfarenhet av att bli kränkt eller missgynnad i mötet med sjukvården.

Samtliga intervjuer har transkriberats och sedan lästs som faktiska empiriska skildringar. Det innebär att vi inledningsvis inte har ifrågasatt innehållet utan läst intervjuerna som sanna berättelser om levda erfarenheter. Frågor som styrt vårt läsande i detta skede har varit: vad handlar berättelsen om, när och var inträffade det som återges och hur upplevde personen det som hände? Vi har således i första ledet av vår analys försökt skapa oss en överblick av situationen som berättelsen handlar om. För att kunna sätta in berättelserna $i$ ett större sammanhang har vi emellertid i det andra analytiska steget brutit ned berättelsens innehåll i olika teman. Dessa teman behöver inte ha motsvarat de i intervjuguiden utan är vad som framkommer ur berättelserna. Frågan som styrt vårt läsande i den andra läsfasen är: varför inträffade den händelse som återges?

Intervjuerna har först tematiserats enskilt. Sedan har de jämförts för att se vilka teman som är unika berättelser och vilka som är återkommande för alla. Vår redogörelse inkluderar både teman som är återkommande för alla äldre migranter och de professionella och de som är specifika för de äldre kvinnliga migranterna. De presenteras i artikeln under följande rub- 
riker; strukturella hinder för likvärdighet, kvinnornas erfarenheter av olikvärdigt bemötande, professionella blockeringar samt vägar till likvärdigt bemötande. Varje tema illustreras genom att vi citerar våra intervjupersoner för att lyfta fram deras berättelser och erfarenheter. Citaten är redigerade så att talspråk korrigerats och småord, upprepningar och liknande har strukits.

\section{Olikvärdighetens former och uttryck i sjukvården}

\section{Strukturella hinderför likvärdighet}

I intervjuerna med både äldre migranter och professionella framkommer att ekonomiska och organisatoriska strukturer resulterar i olikvärdig tillgång till sjukvård. Men de strukturella hindren beskrivs från helt olika utgångspunkter. De äldre migranterna skildrar hur ekonomisk utsatthet gör att de saknar pengar för provtagningar, behandlingar, uppföljningar och medicinering, medan de professionella främst lyfter fram de problem som skapas av ekonomistyrning och rationaliseringar.

Tidigare studier visar att den ekonomiskt mest utsatta gruppen bland äldre migranter i Sverige är personer som migrerat sent i livet (Ekberg \& Lind, 2011; Linné, 2005; Torres, 2006). Ofta lever dessa personer på en skör kombination av minimibelopp från garantipensionen, försörjningsstöd och finansiell hjälp från släktingar. Denna ekonomiska utsatthet framträder även i våra intervjuer. Två 70-åriga kvinnor vi intervjuade som båda migrerat till Sverige sent i livet berättar att deras låga inkomster sällan räcker till att betala de läkarbesök, mediciner och hjälpmedel de är i behov av.

Om man är pensionär fär man bara en viss summa, spelar ingen roll om $d u$ köper jättemycket mediciner och mycket hjälpmedel. På $4200 \mathrm{kr}$ måste man klara av att betala all medicin, [besök på] vårdcentral och läkarbesök.

Tandläkarbesök är för vissa äldre migranter otänkbart eftersom det ofta innebär höga kostnader. Förutom problemet med att tandläkarvården är dyr anser emellertid inte de professionella vi intervjuade att de äldre migranternas privatekonomi påverkar möjligheterna till likvärdig sjukvård. En läkare på en geriatrisk enhet menar exempelvis att oavsett om den äldre personen är migrant eller inte så är det största problemet för äldre personer inte sjukvården utan kostnaden för hemtjänsten, som enligt hans erfarenhet många äldre personer oroar sig för. Med undantag för de professionella som arbetar på asylmottagningar och som därför dagligen kommer i kontakt med personer som lever i en utsatt situation, verkar därför professionella inom sjukvården generellt inte förstå att ett läkarbesök eller mediciner kan bli för dyra för en äldre person som inte är berättigad till full garantipension och som inte heller har ekonomiska besparingar att ta av. Inte heller finns någon medvetenhet om att högkostnadsskyddet i sig kan fungera som en barriär. Tidigare studier har emellertid 
pekat på just det faktum att högkostnadsskyddet nollställs efter ett år och utgör ett stort problem för de människor som lever på existensminimum (Burström, Schultz, Burström et al, 2007). Konsekvensen blir att personer med mycket låga inkomster istället väljer att avstå från läkarbesök och mediciner trots att de är i behov av dessa.

Personal, tjänstemän och representanter från intresseföreningar beskriver emellertid hur organisatoriska förhållanden skapar olikvärdig tillgång till sjukvård. Dessa utgörs främst av en slimmad arbetsorganisation, hög arbetsbelastning, tidspress, begränsat antal vårdplatser, bristande koordinering mellan olika enheter och ett prestationsbaserat ersättningsystem. De flesta av dessa faktorer kan kopplas till den ekonomistyrning och de rationaliseringar som genomförts inom sjukvården de senaste 20 åren, som ökat risken för samvetsstress och etiska rollkonflikter bland sjukvårdspersonalen (Målqvist, Åborg \& Forsman, 2011). Det speglas också i våra intervjuer med de professionella. Intervjuerna ger en samstämmig bild av att ekonomistyrningen och rationaliseringarna skapat en prioriteringsordning inom sjukvården som ger företräde till patienter med åkommor som är enkla och snabba att åtgärda, medan patienter som uppfattas som svårbedömda och svårbehandlade hamnar på undantag. Enligt en tjänsteman drabbar detta i synnerhet personer som behöver insatser från både kommunen och landstinget.

Både äldre och psykiskt funktionshindrade och andra som har behov av stöd från både kommuner och landsting ris- kerar att komma på undantag i så motto att de verkligen skulle må bra av en helhetssyn. De kan fä massor av insatser, men de fär aldrig den där helheten.

Intervjuerna med de professionella pekar sammantaget på hur ekonomistyrning och rationaliseringar skapat en sjukvårdsorganisation som ger företräde till dem som kan stå upp för sina rättigheter. En representant för en etnisk intresseförening kallar uttryckligen det svenska sjukvårdssystemet för "...en plattform där den starke får sin rätt." Personer som inte kräver sin rätt, vilket kan vara mycket svårt om en inte talar svenska eller inte är insatt i hur systemet fungerar, riskerar således att bli förbisedda i den svenska sjukvården.

\section{Kvinnornas upplevelser av olikvärdigt bemötande}

Ett centralt och återkommande tema i de äldre kvinnliga migranternas berättelser om deras möten med sjukvården i Sverige är bristande respekt och verbala kränkningar. Detta står i stark kontrast till de äldre manliga migranterna som generellt säger sig vara nöjda med svensk sjukvård. I synnerhet de äldre muslimska kvinnorna berättar om upprepade verbala kränkningar från både läkare och sjuksköterskor. Ofta har dessa kränkningar inträffat på vårdcentralen när kvinnorna sökt hjälp för mindre allvarliga olyckor eller smärta och värk. Istället för ett professionellt bemötande har kvinnorna tillbakavisats som besvärliga "icke-patienter". Med detta menar vi att kvinnorna har avvisats som 
vårdsökande personer och istället betraktas som friska individer som tar sjukvårdens tid och resurser $i$ anspråk utan att vara i behov av dem.

En kvinna i 50-års ålder beskriver exempelvis hur hon gick till vårdcentralen efter en halkolycka. Hon hade skadat sitt ben och slagit huvudet så hårt att hon hade ihållande susningar i öronen. Läkaren frågade om hon ville ha sjukintyg varpå kvinnan svarade att hon inte hade råd att vara sjukskriven utan ville bara få hjälp med värken i sitt ben och susningarna i öronen. Läkaren svarade då att det inte var något fel på henne annat än att hon var överviktig och måste börja banta:

Sedan sa jag till henne: mitt ben, jag ramlade och det susar $i$ mina öron och jag har ont i benet. "Jobbar du? Behöver du sjukskrivning?" Nej, snälla, jag frågar inte [om det], jag säger inte [det här] för att fä bli sjukskriven, bara att [du] undersöker mig. "Det finns ingenting i dina öron. Benet - du ska gå till fotvård." Men jag säger [jag har] ont i hela benet, inte i foten. Hon sa: "du är tjock och rund, du ska gå ned i vikt."

Tilläggas ska att vi som genomförde intervjun inte kunde se att läkarens uttalande om bantning på något sätt stämde överens med kvinnans kroppskonstitution. Hennes berättelse är emellertid karakteristisk för de äldre muslimska kvinnor vi intervjuade. För det första organiseras mötet runt utfrågningar om sjukskrivning. Kvinnan i citatet ovan beskriver under intervjun denna utfrågning närmast som ett korsförhör. Det är något som även andra muslimska kvinnor bekräftar. I synnerhet på vårdcentralerna verkar läkarna utgå från att muslimska kvinnor generellt är ute efter ett sjukintyg. Ingen av de kvinnor vi intervjuade varken ville eller kunde bli sjukskrivna eftersom de inte har råd att vara borta från arbetet eller SFI (svenska för invandrare). En annan muslimsk kvinna i 50-års ålder summerar inställningen personalen på vårdcentralen har som:"De som går på SFI, de vill stanna hemma och de vill ha pengar utan jobb, så tror jag de tänker."

Det andra som är kännetecknande och återkommer i de äldre muslimska kvinnornas berättelser är att deras hälsoproblem avfärdas som bagateller eller rent nonsens. Särskilt när de söker hjälp för hälsoproblem relaterade till smärta. En kvinna i 70-års ålder berättar exempelvis att hennes läkare avfärdat hennes smärta och värk i huvudet, axlarna och benen med "det är vanligt, du är gammal." Att vårdpersonalen förringar betydelsen av kvinnornas smärtproblematik kan emellertid få förödande konsekvenser. En av de muslimska kvinnorna vi intervjuade hade under två års tid sökt hjälp både på vårdcentralen och akutenheten för kraftiga smärtor i ryggen och bröstet och för diarréer. Trots att hon ibland fick åka in akut med ambulans gjordes ingen medicinsk utredning utan hon skickades hem med recept på olika värktabletter. Till slut fick hon via sin dietist hjälp att träffa en läkare som snabbt konstaterade att hon hade en långt framskriden cancer och att hon var så illa däran att hon kanske inte skulle överleva operationen. När vi genomförde intervjun var hon fortfarande inte säker på om hon skulle överleva sjukdomen efter- 
som läkarna misstänkte att cancern hade spridit sig. Föga förvånande beskrev denna kvinna vårdcentralen hon varit registrerad på som diskriminerande och inkompetent.

De trodde inte på mig. Om jag inte hade tagit den där kopian [på röntgenplåtarna] till dietisten och hon lämnade dem vidare till en annan läkare skulle jag ha dött utan att veta orsaken. Så vården här [på vårdcentralen] är skit, ursäkta mig, för de tar inte invandrare påallvar.

Att äldre kvinnliga migranter med smärtproblematik ofta blir illa behandlade i sjukvården bekräftas även i intervjuerna med professionella. En psykiatriker och en läkare vi intervjuade erkänner båda att de anser att kvinnliga migranter med smärtproblematik tillhör de patienter de har svårast att behandla. Dels kan det vara svårt att förstå orsaken till patientens smärta om hon pratar via tolk. Dels kan smärtan vara ett symtom på existentiella, sociala och/eller ekonomiska svårigheter som följer med migrationen. Sådana gånger finns det stor risk att kvinnan bara skickas runt i vården utan att få någon substantiell hjälp. Ytterligare en läkare vi intervjuade menar emellertid att grundproblemet ligger i sjukvårdens prioritering av människor. På vår fråga om vilka hinder en äldre kvinna som är migrant möts av i sjukvården svarar läkaren krasst:

Du har hela spektret där, då är du liksom lägst ned på skalan. Du fär vänta mycket - längst - och längre väntan på återbesök. Det tas färre prover, du fär billiga läkemedel, du får mycket psykiska läkemedel. Det finns ju en radda bara för att du har just den här kombinationen av flera saker.

Påfallande i våra intervjuer med de äldre kvinnliga migranterna är att hög utbildning och kunskaper i svenska inte nämnvärt verkar förändra hur de blir bemötta i sjukvården. Framför allt de äldre kvinnor som är muslimer beskriver hur de blir bemötta som om de är okunniga och oförmögna att ta till sig grundläggande medicinsk information, oavsett om de har en högskolexamen eller inte och oaktat om de pratar flytande svenska eller inte. En av kvinnorna vi intervjuade har exempelvis en gymnasielärarexamen från sitt hemland och pratar flytande svenska. Hon menar att fördomar om muslimska kvinnor är vanliga i Sverige och finns i lika hög grad inom sjukvården som utanför den. Det får också konsekvenser för bemötandet av muslimska kvinnor i sjukvården:

Några folk här i Sverige tror att vi som har sjal på oss, vaira föräldrar och familjen hindrar oss att gå till skolan och vi förstår inte. Vi kan inte läsa. Vi kan inte skriva och så. De har den här idén-och husläkare också. Sköterskor eller läkare, de tror att vilket som helst går bra för oss. De behöver inte visa oss respekt eller de tror vi är analfabeter.

\section{Professionellablockeringar}

Bemötande som särskiljer patienter bryter mot hälso- och sjukvårdslagens intentioner om likvärdighet. Vi menar att sär- 
skiljande strukturer och praktiker inom sjukvården kan härledas till en inbyggd konflikt mellan lika och likvärdig behandling. Det professionella handlandet inom sjukvården bygger i hög utsträckning på en etik som utgår från likhet (Johnstone \& Kanitsaki, 2010; Nilsson, 2010). De professionella som vi intervjuade återkommer ofta till denna utgångspunkt. En läkare sammanfattar exempelvis det professionella handlandet som:

Vi är här för att behandla symtom och det handlar väl om att bortse från hudfärg och etnicitet och behandla alla lika helt enkelt, utifrain deras medicinska behov. Man är ungefär likadant skapt rent anatomiskt och fysiologiskt och sedan vad man tror på eller hur man ser ut det påverkar inte oss.

Att arbeta i en organisation som styrs av ett sådant starkt - men naivt - likhetstänkande innebär emellertid att ens antydan om att det förekommer en selektiv behandling av patienter framstår som en direkt provokation (FRA, 2013; Nilsson, 2010). Resultatet blir att det professionella handlandet i sjukvården också omfattar vad Nilsson (2010) kallar för en tabukultur, som inbegriper tystnad om patienter far illa, en oförmåga till självkritik samt att inte kunna ge konstruktiv kritik till kollegor (se även Brüggemann, Wijma \& Swahnberg, 2011). Det professionella handlandet i sjukvården karaktäriseras också av stark kollegialitet. Som sjukvårdspersonal "skvallrar" man inte på varandra utan man håller kolleger bakom ryggen och tillrättavisar definitivt inte en kollega inför en patient (Nilsson, 2010). Likhetstänkandet, tabukulturen och den starka kollegialiteten resulterar emellertid i professionell blockering som gör det svårt för sjukvårdspersonal att se och förstå hur deras personliga fördomar kan resultera i att de bemöter och behandlar människor olikvärdigt.

Omfattande amerikansk forskning visar att särskiljande praktiker i sjukvården sällan är följden av medvetna handlingar från personalens sida (se exempelvis IOM, 2002; Moskowits, Stone \& Childs, 2012). Olikvärdig behandling är istället resultatet av omedvetna fördomar och indirekt stereotypifiering som ofta "triggas" av osäkerhet om patientens medicinska tillstånd. Språk och medföljande kommunikationssvårigheter kan vara en katalysator för fördomar och indirekt stereotypifiering. Flera av de professionella som vi intervjuade återkommer till att de själva har blivit förargade på patienter som inte kan prata svenska och/eller så har de hört kollegor blir irriterade. En gynekolog berättar exempelvis hur hon och hennes kollegor retar sig på patienter som inte kan prata svenska trots att de bott i Sverige en längre tid:

Ibland har jag hört det här bland kollegor att jag tycker man ska ha gratis tolk tills man har bott i Sverige i två år, sedan fär man faktiskt lära sig svenska så man kan gå till doktorn. Ibland kan jag nästan tycka själv också att ett visst antal år, sedan får tolkarna vara till dem som är nyanlända som absolut inte kan [prata svenska]. 
Samtidigt påpekar en sköterska hur hon upprepade gånger hört vårdpersonal öppet kränka personer som bryter på svenska.

Det finns ju människor som inte vill förstå om någon kommer fram till dig och frågar något på en väldigt bruten svenska, trots att man faktiskt kan höra vad de säger, men de säger fel, använde fel ord eller någonting, som inte vill förstå utan som diskriminerar på det sättet: "Jag förstår inte vad du säger. Du fär ta med dig någon som kan förklara vad du säger."

Citaten ovan speglar hur språksvårigheter kan utlösa olikvärdigt bemötande. Gynekologens reflektioner indikerar hur hälso- och sjukvårdspersonalen upplever språkfrågan som ett underliggande irritationsmoment i mötet med migranter, särskilt om de har bott en längre tid i Sverige men fortfarande har problem med språket.Sjuksköterskans erfarenheter pekar på att personal både kränker och nedvärderar patienter på grund av kommunikationssvårigheter. Det motsäger likhetstanken som läkaren gör gällande - det vill säga att det professionella handlandet i sjukvården enbart styrs av symtom, anatomi och fysiologi. Oavsett om det är medvetet eller omedvetet är det viktiga i sammanhanget att personer de facto inte behandlas likvärdigt. Ett likvärdigt bemötande tar hänsyn till de sammanhang, förhållanden och förmågor som villkorar personers eller gruppers möjligheter här och nu. Ett professionellt handlande grundat på likvärdighet borde således utgå från att per- soner som inte har svenska som modersmål inte heller har samma förutsättning att kommunicera på svenska som en person som har svenska som modersmål. Språkfrågan antyder även hur framför allt äldre migranter riskerar att bli utsatt för olikvärdigt bemötande, eftersom ålder kan påverka förmågan till språkinlärning. $\AA$ ena sidan förväntas äldre migranter kunna kommunicera själva med sjukvårdspersonal efter att de vistats ett hypotetiskt antal år i Sverige. Å andra sidan riskerar de att bemötas med arrogans och oförskämdhet om de försöker kommunicera utan att prata god svenska.

Att personalen inte förstår hur språksvårigheter påverkar mötet i sjukvården framkommer i intervjuerna med de äldre kvinnliga migranterna. Som personerna påpekar är det ytterst svårt att göra sin röst hörd i sjukvården om man inte behärskar det svenska språket. En äldre muslimsk kvinna säger exempelvis att hon inte vågar klaga på läkaren som föreskrivit henne en medicin med svåra biverkningar utan att tala om detta för henne. Hon anser sig tala för dålig svenska för att själv kunna framföra sina klagomål och hon litar inte på att tolken ska översätta hennes klagomål korrekt.

Tabukulturen, det vill säga tystnad och kollegial uppslutning även om patienter far illa, är emellertid en minst lika viktig orsak till svårigheterna att få upprättelse i sjukvården. Erfarenheterna från en annan äldre muslimsk kvinna vi intervjuade utgör ett påtagligt exempel på detta. Hon har en allvarlig och permanent vårdskada på grund av en felaktigt utförd operation. Hon fick ett muntligt erkännande av sjuk- 
vårdspersonalen om skadan och dess konsekvenser efter operationen. Men när hon begärde ut sina journaler i samband med att hon skulle anmäla felbehandlingen upptäckte hon att läkarna inte hade journalfört och dokumenterat hennes skada. Trots att hon upprepade gånger har försökt få en förklaring till varför sjukvården "struntat i" att dokumentera hennes skada har hon aldrig fått något svar. Inte heller har hon kunnat anmäla felbehandlingen eller begära skadestånd från patientförsäkringen eftersom hennes skada är odokumenterad. Denna kvinna sammanfattar sina bittra erfarenheter av svensk sjukvård som: "Det finns så mycket fiffel och de hailler ihop och du kan inget bevisa."

\section{Vägar till likvärdigt bemötande}

I intervjuerna med de äldre migranterna bad vi dem beskriva och ge exempel på vad de bedömer som god vård. ${ }^{4}$ I motsats till de negativa erfarenheterna av svensk sjukvård så kretsar berättelserna om god vård nästan uteslutande omkring två teman; empati och kompetens. Båda beskrivs som grundläggande och oumbärliga beståndsdelar för upplevelsen av ett gott bemötande och god behandling. Ordagrant beskriver alla äldre migranter, oavsett kön, empati och kompetens som att personalen är trevlig, att de bryr sig, att de frägar och följer upp hur deras patienter mår. Vad som sägs i intervjuerna med de äldre migranterna är således att upplevelsen av lik-

4 Detta tema återkom i alla intervjuer med patienter. värdigt bemötande i sjukvården bestäms av hur väl sjukvårdspersonal kombinerar professionellt handlande med hänsyn till den person som de möter.

Att empati och kompetens är avgörande för upplevelser av likvärdigt bemötande låter trivialt. Men sjukvårdspersonalen beskriver hur problematiskt det kan vara att förena professionell kompetens med empati i tvärkulturella kontexter. Ett dilemma handlar om att kunna balansera mellan medicinsk vårdetik och respekt för kulturella olikheter. En sjuksköterska som arbetar på en palliativ vårdavdelning berättar exempelvis om en situation där manliga släktingar krävde att all kommunikation med patienten, som var en äldre kvinna, skulle ske genom dem. Palliativ vård är en komplex verksamhet. Den ska både lindra patientens smärta och andra symtom vid livets slut och erbjuda psykologiskt och existentiellt stöd för såväl patient som närstående. Sjuksköterskan beskriver hur språksvårigheter försvårade ett likvärdigt bemötande av både patienten och hennes anhöriga. All kommunikation med den äldre kvinnan och hennes anhöriga skedde genom tolk. Men på grund av språksvårigheter förstod inte de manliga släktingarna syftet med en palliativ behandling. De kunde därför exempelvis kräva att de skulle godkänna vilka sprutor som den äldre kvinnan skulle få. Om det inte fanns en tolk att tillgå när detta inträffade och personalen ändå vidhöll nödvändigheten av att ge den äldre kvinnan sprutorna för att kunna lindra hennes smärtor hände det att de manliga släktingarna uppträdde aggressivt. Sjuksköterskan beskriver hur hon fick anstränga sig extra 
hårt vid dessa tillfällen för att både kunna lugna de manliga släktingarna och samtidigt pedagogiskt förklara varför den äldre kvinnan måste få sina sprutor. Att uppnå ett likvärdigt bemötande i komplexa vårdsituationer som detta ställer således höga krav på empati och professionell kompetens.

En annan förutsättning för likvärdighet i sjukvården som personalen beskriver är förmågan att tänka i nya banor och handla därefter. En sjukgymnast berättar till exempel att de har problem med att få en del muslimska kvinnor att delta i vattengymnastik. Vissa vill träna med kläderna på och vill inte heller träna tillsammans med män i bassängen. För att lösa dilemmat har sjukgymnasten startat speciella kvinnogrupper där patienterna också får träna med kläderna på. Hon beskriver emellertid att hon fått arbeta hårt för att få igenom de speciella kvinnogrupperna och att hon även motarbetas av andra $\mathrm{i}$ personalgruppen.

$V i$ har problemet $i$ bassängen att man vill ha speciella kvinnogrupper och att man då vill ha kläder och slöjor och så på sig. Och det finns ju absolut fördomar och personal som är irriterade på dem"varför måste de ha speciella grupper?"

En tredje förutsättning för att kunna uppnå likvärdighet i sjukvården är att personalen avsätter tid för att skapa sig en komplett bild av de symtom som patienten söker vård för. Detta kan vara svårt eftersom tidsbrist är ett ständigt närvarande problem i sjukvården. Inte minst $\mathrm{i}$ dagens sjukvårdsorganisationer som styrs av prestationsbaserade ersättningssystem. En läkare som arbetar på en vårdcentral som infört prestationsbaserad ersättning berättar hur hon på följande sätt försöker "lura" systemet för att kunna uppnå en likvärdig behandling av vissa patienter. Får hon en akut patient där hon misstänker att andra faktorer än rent medicinska är grundorsaken till patientens tillstånd försöker hon alltid boka in ett andra möte där hon kan avsätta tid för samtal. Ofta handlar det om patienter med misstänkt krigstrauma.

Vissa har till exempel varit med $i$ krig, då frägar jag lite mer. Kanske jag inte frågar svenskar om de har varit med $i$ krig. Men det här frägar jag alltid [ migranter]; från vilket land de kommer, har de varit med $i$ krig eller inte, har de förlorat sina barn eller anhöriga. Det är mainga som kommer frän Somalia. De har redan förlorat många släktingar och anhöriga och det är viktigt att fräga om.

Den fjärde - och kanske den mest grundläggande - förutsättningen för att åstadkomma likvärdigt bemötande i sjukvården är ett normkritiskt förhållningssätt. Normkritik innebär i korthet att fokusera på de värderingar och strukturer som gör att vissa individer eller grupper uppfattas som avvikare (Edgren, 2013). Ett normkritiskt förhållningssätt innebär således att vända blicken från de som utpekas som "avvikare" till att granska de processer som skapar dessa maktförhållanden. Detta kräver emellertid ett självkritiskt personligt förhållningssätt. En läkare som vi intervjuade lyfter fram att självkännedom 
och förståelse för de maktförhållanden som omger själva vårdmötet är avgörande för att kunna bemöta patienter likvärdigt.

Det har ju med normer och värderingar [att göra] och mitt sätt att bemöta och den hjälp du får i sjukvården, där man är så utelämnad. För man är ju väldigt utelämnad i vården. Man kommer ju dit för att man inte mår bra. Då kräus det att jag som möter dig är medveten om vem jag är och vem jag möter. Och vad det här spelet emellan är - om det är en kvinna som möter en kvinna eller om det är en man som möter en man och en kvinna som möter en man och tvärtom.

Sammanfattningsvis är både de äldre migranterna och personalen överens om att likvärdighet $\mathrm{i}$ sjukvården förutsätter en organisation och en profession där det avgörande är viljan och förmågan att se och att möta människor som söker vård utifrån deras egna premisser. Det kräver emellertid en flexibel organisation som tillåter personalen att avsätta tid och resurser för utsatta grupper och individer. Men det kräver också en profession som har insikt $i$ att den inte är ofelbar utan att den präglas av samma värderingar, fördomar och socialt skapade makthierarkier som finns i samhället i övrigt.

\section{Diskussion och slutsatser}

Vi har i den här artikeln pekat på de paradoxala konsekvenserna av lika behandling inom sjukvården. Som Fineman (2004; 2008) påpekar i sin teori om utsatthet utgår begreppet lika behandling ifrån ett abstrakt likhetstänkande där alla människor tillskrivs likvärdiga positioner. Men som vi visat i bemötandet av äldre kvinnliga migranter i sjukvården kan lika behandling de facto bli ojämlikhet eftersom människor i realiteten inte har likställiga utgångspunkter. Vi menar därför att i verksamheter som arbetar med personer som befinner sig i särskilt utsatta situationer, som socialtjänsten, äldreomsorgen och hälso- och sjukvården, blir det viktigt att skilja på likhet och likvärdighet. Medan likhet utgår från antagandet att alla klienter, brukare eller patienter faktiskt har samma och lika möjligheter att agera, utgår likvärdighet från de sammanhang, förhållanden och förmågor som villkorar den enskildes möjligheter här och nu. För de som arbetar inom socialtjänsten, äldreomsorgen eller hälso- och sjukvården innebär därför likvärdighet att det professionella bemötandet bör utgå från klienters, brukares och patienters olika förutsättningar snarare än normativa ideal om lika behandling. Ett professionellt bemötande baserat på likvärdighet ställer emellertid höga krav på förmågan att förena empati och professionell kompetens, vilket exemplen i den här studien visar.

Vad är det då som gör att människor inte känner sig likvärdigt bemötta? Vi har i den här artikeln spårat denna process genom att utgå från hur äldre kvinnliga migranter upplever bemötandet i hälsooch sjukvården. Mot bakgrund av att det verkar finns ett mönster i upplevelsen av att vara utsatt för diskriminering, oavsett diskrimineringsgrund eller samhällsområde (DO, 2014), menar vi att våra resultat även kan användas för att förebygga upp- 
levelser av kränkningar och särbehandling inom andra områden än sjukvården, som exempelvis äldreomsorgen och socialtjänsten.

Vår studie indikerar att bemötandet i hälso- och sjukvården styrs av ett simultant skillnadstänkande baserat främst på nationellt ursprung, kön, religion och ålder. Konkret innebär detta att äldre kvinnliga migranter som också är muslimer riskerar att utsättas för negativ stereotypifiering, det vill säga att de blir associerade med fördomar om äldre, invandrade muslimska kvinnor i Sverige. Den internationella studie, som utgjort ramen för de intervjuer som vår artikel bygger på, visar att det är vanligt förekommande att muslimska kvinnor oavsett ålder utsätts för negativ stereotypisering i sjukvården (FRA, 2013). Resultaten i denna artikel tyder emellertid på att ålder ibland kan cementera denna process på så vis att ålder kan förstärka fördomarna och förringa betydelsen av kvinnornas hälsoproblem.

Analysen visar även att ett centralt hinder för likvärdighet är att sjukvårdspersonalen inte kan se eller förstå att de bemöter människor ojämlikt. Personalen är helt enkelt inte medveten om sina egna fördomar. Vi benämner detta som professionell blockering. Att förutfattade meningar resulterar i professionella blockeringar är emellertid inget unikt för hälso- och sjukvårdspersonal. Detta inträffar även inom den kommunala äldreomsorgen samt inom socialtjänsten (Mattsson, 2010; Torres, 2006). Återkom- mande utbildning och träning i normkritik skulle därför kunna bidra till att stärka likvärdigheten i det professionellt bemötande inom sjukvården, äldreomsorgen och socialtjänsten.

Lagstiftaren har i flera decennier haft som mål att skapa likvärdighet inom sjukvården och socialtjänsten. Men mot bakgrund av våra resultat framstår lagstiftningens förmåga att stärka likvärdigheten som begränsad. Vår studie visar att likvärdighet kräver professionell insikt av yrkeskåren. Så länge det saknas en förståelse för att det finns en potentiell konflikt mellan lika och likvärdigt bemötande går det knappast att förvänta sig några positiva förändringar. Lika viktigt som den professionella insikten är emellertid att personal som arbetar med utsatta individer får möjlighet att avsätta den tid och de resurser som krävs för ett likvärdigt bemötande. Våra resultat pekar på att så är inte fallet i dagens ekonomistyrda sjukvårdsystem. Verksamma på alla organisatoriska nivåer inom sjukvården behöver därför få insikt om den olikvärdighet som (mer eller mindre omedvetet) upprätthålls i vården idag. Här behövs insikt om att likvärdighet aldrig kan bli detsamma som likhet. Den ojämlikhet som personal och andra företrädare för verksamheter som likt sjukvården arbetar med utsatta människor uppfattar kan inte förebyggas genom föreställningar om att alla människor har samma valmöjligheter. Ett sådant förhållningssätt får snarare motsatt effekt, vilket denna studie åskådliggör. 


\section{Referenser}

Brüggemann, J., Wijma, B. \& Swahnberg, K. (2011) Patients' silence following healthcare staff's ethical transgressions. Nursing Ethics 19(6), 750-763.

Burström, B., Schultz, A., Burström, K., Fritzell, S., Irestig, R., Jensen, J., Lynöe, N., Marttila, A. \& Sun, S. (2007) Hälsa och livsvillkor bland socialt och ekonomiskt utsatta grupper i Stockholms län. Stockholms läns landsting: Enheten för Socialmedicin och Hälsomedicin, Centrum för Folkhälsa \& FOURM för kunskap och gemensam utveckling.

Cameron, K., Song, J., Manheim, L. \& Dunlop, D. (2010) Gender disparities in health and healthcare use among older adults. Journal of Women's Health 19(9), 1643-1650.

de los Reyes, P. \& Mulinari, D. (2005) Intersektionalitet: kritiska reflektioner över (o)jämlikhetens landskap. Malmö: Liber.

DO (2012) Rätt till sjukvård på lika villkor. Stockholm:DO.

DO (2014) Delar av mönster - en analys av upplevelser av diskriminering och diskriminerande processer.Stockholm:DO.

Edgren, M. (2013) Diskriminering av kvinnor: om nödvändigheten av ett intersektionellt och normkritiskt perspektiv. I: Blomberg E \& Niskanen K (red.) Arbete och jämställdhet: förändringar under 50 arr. Stockholm: SNS.

Ekberg, J. \& Lindh, T. (2011) Pensionsreformen och invandrarna. Ekonomisk Debatt 39(5), 33-40.

Fineman, M. A. (2004) The Autonomy myth: A Theory of Dependency. New York: The New Press.

Fineman, M. A. (2008) The vulnerable Subject: Anchoring Equality in the Human Condition. Yale Journal of Law and Feminism 20(1), 1-24.

Fioretos, I. (2009) Möten med motstånd: kultur, klass, kropp på vårdcentralen. Akad. avh. Lunds Universitet: Inst. för kulturvetenskaper.

European Union Agency for Fundamental Rights (FRA) (2013) Inequalities and multiple discri- mination in access to and quality of health care Vienna: European Union Agency for Fundamental Rights.

Garland-Thomson, R. (1997) Extraordinary bodies: figuring physical disability in American culture and literature. New York: Columbia University Press.

Hagman, L. \& Östberg, J. (2010) Utnyttja möjligheterna. Organiseringen av hemsjukvård vid åtta husläkarmottagningar. Stockholm: Stiftelsen Stockholms läns Äldrecentrum.

Institute of Medicine (IOM) (2002) Unequal Treatment: Confronting Racial and Ethnic Disparities in Health Care. Washington, DC: the National Academic Press.

Johnstone, M, \& Kanitsaki, O. (2010) The neglect of racism as an ethical issue in health care. Journal of Immigrant and Minority Health 12(4), 489-495.

Linné, S. (2005) "Jag förstår inte vad dom säger". Äldre invandrare i Malmö berättar om vård och omsorg. Malmö: Malmö FoU-enhet för äldre.

Mattsson, T. (2010) Intersektionalitet $i$ socialt arbete. Malmö: Gleerups.

McCall L. (2005) The complexity of intersectionality. Signs 30(3), 1771-1800.

Moskowits, G.B., Stone, J. and Childs, A. (2012) Implicit Stereotyping and Medical decisions: Unconscious Stereotype Activation in Practitioners' Thoughts about African Americans. American Journal of Public Health 102(5), 9961001.

Målqvist, I., Åborg, C. \& Forsman, M .(2011) Styr former och arbetsförhaillanden inom vård och omsorg - en kunskapssammanställning om New Public Management. Stockholm: Karolinska Institutet.

Nilsson, A. (2010) Evaluering av projektet "Kränkningar $i$ vården". Linköping: Hälsouniversitetet,Linköpings Universitet.

Prop. 2008/09:29, Lag om valfrihetssystem.

Prop. 2013/14:106, Patientlag. 
Schön, P. (2011) Gender matters. Differences and change in disability and health among our oldest women and men. Diss. Department of Social Work: Stockholm University.

Socialstyrelsen (2009) Hälso- och sjukvårdsrapport 2009. Stockholm: Socialstyrelsen.

Socialstyrelsen (2011) Ojämna villkor för hälsa och vård. Jämlikhetsperspektiv på hälso- och sjukvården. Stockholm: Socialstyrelsen.

Torres, S. (2006) Elderly Immigrants in Sweden: 'Otherness' Under Construction. Journal of Ethnic and Migration Studies 32(8), 1341-1358.
Wamala, S. \& Lynch, J. (Eds.) (2002) Gender and social inequities in health. Lund: Studentlitteratur.

Wamala, S., Merlo, J., Boström, G. \& Hogstedt, C. (2007) Perceived discrimination, socioeconomic disadvantage and refraining from seeking medical treatment in Sweden. Journal of Epidemiology \& Community Health 61(5), 409415.

Yuval-Davies, N. (2011) The politics of belonging: intersectional contestations. Los Angeles: Sage. 


\section{Summary}

\section{At the bottom of the ladder? The treatment of older female migrants in Swedish healthcare}

This article aims to investigate the treatment of older female migrants in Swedish healthcare. The study puts the emphasis on exploring if there are differences in the interpersonal treatment of older female migrants that make them feel discriminated against. The theoretic inspiration for the article comes from Fineman's vulnerability theory and intersectional perspectives on equality. A critical approach to the understanding of equality as sameness of treatment is central to the study. Drawing upon 37 semi-structured interviews with health professionals and older female migrants, the article shows several inequalities in access and treatment of older female migrants. Inequalities in access relate to economic and organizational barriers that generate unequal access to healthcare for older female migrants. Inequalities in treatment concern stereotyping and offensive behaviour on the part of the staff, which particularly affects older Muslim women searching help for aches and pains. Overall, health professionals seem to be unaware of these discriminatory practices. The study suggests that one explanation for this lack of awareness on the part of the professionals is the interpretation of equality as sameness of treatment. The problem with this understanding is that it ignores differences in the circumstances and abilities of the patient. Treating everybody the same turns into inequality, as the financial conditions and linguistic abilities of older migrants mostly are different from those of the native population. Therefore, the article concludes that professionals who, like healthcare personnel, are working with vulnerable individuals need to develop alternative approaches to equal treatment that includes the context of the patient. 